\title{
Incidence of Pododermatitis in Broiler Reared under Two Types of Environment
}

http://dx.doi.org/10.1590/1806-9061-2015-0047

-Author(s)

\section{Jacob FG'}

Baracho MS'

Nääs IA'

Salgado DA'

Souza R'

College of Agricultural Engineering, State University of Campinas, Brazil

\section{a Mail Address}

Corresponding author e-mail address Jacob FG

College of Agricultural Engineering, State University of Campinas, Brazil

Email: flahjacob@yahoo.com.br

\section{ABSTRACT}

Housing environment is essential to achieve good broiler performance and to prevent diseases, including footpad dermatitis (FPD). The objective of this study was to determine the incidence of footpad dermatitis in broilers chickens according to housing type. The study was carried out with broilers reared for 5, 12, 19, 29 and 40 days. Four houses were used in this observational study. House 1 (A1) had positive pressure and reused litter; house 2 (A2) had positive pressure and new litter (sawdust); house 3 (A3) had positive pressure and new litter (rice husks); and house 4 (A4) had negative pressure and reused litter. During the entire experiment, air environmental and litter surface temperatures, and litter compaction were recorded. Pododermatitis was assessed by visual scoring of the footpads. Footpads were scored as function of the severity of the lesion. The comparison of means by the test of Bonferroni at 95\% confidence interval showed higher incidence of footpad dermatitis in A3, probably due to the particle size of litter substrate. The lowest footpad dermatitis incidence was found in $A 1$, with reused sawdust litter.

\section{INTRODUCTION}

The first cases of footpad dermatitis in broilers were recorded in the 1980s (Greene et al., 1985). The disease is called footpad dermatitis and/or contact dermatitis and refers to inflammation of the birds' feet resulting in necrotic lesions of the plantar surface. The lesions may be severe and cause pain, hindering birds to move freely around the house, negatively affecting their welfare (Schmidt \& Luders, 1976; Greene et al., 1985; Ekstrand et al., 1998; Martrenchar et al., 2002; Dawkins et al., 2004; Bilgili et al., 2009; Hoffmann et al., 2013; Harn et al., 2014). In Brazil, footpad dermatitis is used as a welfare indicator in processing plants, and it is regulated by law (BRAZIL, 2010). In the USA and in the European Union, pododermatitis is also used as a criterion for animal welfare assessment (NCC, 2010).

Litter substrate (Ekstrand et al., 1997) and feed composition (Mc Ilroy et al., 1987) are some of the factors that influence the severity of footpad dermatitis. Flock density may negatively affect litter quality, as it increases the amount of excreta in the litter and litter humidity (Vieira, 2011). Other factors affecting the incidence of pododermatitis in a flock are rearing environment conditions (Payne, 1967), enteric infections (Neill et al., 1984), and drinking water hygiene (Elson, 1989). Broiler house ventilation is commonly used to maintain low litter moisture, reducing the incidence of FPD (Tucker \& Walker, 1992; Haslam et al., 2007; Bilgili et al., 2010).

The use of infrared thermal images allows the identification of radiant temperature values in a known surface, and it is a valuable 
tool to understand physiological aspects of animals. This technique allows measuring surface temperature without disturbing the animals, especially of animal body areas that have low heat capacity (Denoix, 1994; Weschenfelder et al., 2013; Nääs et al., 2014).

The Principal Component Analysis (PCA) allows graphically identifying data patterns, and to express them in a manner that highlights their similarities and differences. Small vectors may be neglected. Vectors with the same magnitude and direction are strongly positively associated, while vectors with opposite directions and length are not related. Vectors that present an angle of $90^{\circ}$ are not correlated.

This study aimed at determining the incidence of footpad dermatitis in broilers reared in houses with different ventilation systems and on reused or new litter.

\section{MATERIALS AND METHODS}

The study was carried out in four houses of a commercial broiler farm, in Artur Nogueira county, São Paulo, Brazil (latitude 22 34'23" South, longitude $47^{\circ}$ $10^{\prime} 21^{\prime \prime}$ West, and an altitude of $650 \mathrm{~m}$ ). The climate is characterized by highland tropical climate, with rainfall in summer and dry in winter, with average temperature during the hottest month above $22^{\circ} \mathrm{C}$.

\section{Experimental procedures}

The characteristics of the broiler houses (dimensions, roof material, curtain material and color) and of the birds (housing density, strain) are presented in Table 1.

Broilers were offered a starter feed (1-21 days), a grower feed (22-37 days), and a finisher feed (38-44 days) and water ad libitum in automatic feeders and nipple drinkers.

The broiler houses (Table 1) were divided into three quadrants. The first quadrant was in the air inlet area, the second was in the center of the house, and the third was in the air outlet area. Thermal environment data were registered in the geometric center of each quadrant every two hours during 40 days of the growout period, using a data logger (Hobo, MicroDaq Ltd., New Hampshire, USA). The recorded variables were dry bulb temperature $\left(\mathrm{DBT},{ }^{\circ} \mathrm{C}\right)$, air relative humidity $(\mathrm{RH}, \%)$, and air velocity $\left(\mathrm{AV}, \mathrm{m} \mathrm{s}^{-1}\right)$. Litter surface temperature $\left(\mathrm{LST},{ }^{\circ} \mathrm{C}\right)$ was recorded in two randomlyselected locations in each quadrant at $1 \mathrm{~m}$ from litter, using high resolution (320 x 240 pixels) images made by an infrared thermal camera (Testo 882, Testo Instruments, Lenzkirch, Germany). Litter compaction degree ( $\mathrm{LC}, \mathrm{kg} \mathrm{cm}^{-2}$ ) was registered at the same points the litter surface temperature was recorded, using a portable penetrometer (FT 327, Wagner Instruments, Greenwich, UK). Litter moisture was determined according to the Litter Humidity Determination Degree Method (BRASIL, 1992), with samples collected from two randomly selected locations in each quadrant. Pododermatitis lesions were scored according to a 0-3 scale as: score 0, no lesion; score 1, lesion covered less than $50 \%$ of the footpad; score 2, lesion covered $50-100 \%$ of the footpad; and score 3, lesion covered $100 \%$ of the footpad (Hashimoto et al., 2011). During pododermatitis scoring, footpad surface temperature (FPST, ${ }^{\circ} \mathrm{C}$ ) of each individual bird was registered to assess inflammation. The infrared camera was positioned at $1 \mathrm{~m}$ distance from the target, and the adopted emissivity of skin adopted was 0.95, and 0.91 for the litter (Cangar et al., 2008; Nääs et al., 2010).Footpad surface temperature were recorded in five selected points around footpad using the TESTO software.

\section{Statistical analysis}

Variables related to footpad injury, such as footpad surface temperature $\left(\mathrm{FPST},{ }^{\circ} \mathrm{C}\right)$ and footpad dermatitis scores (FPD) were compared among houses ( $A 1, A 2$, $\mathrm{A} 3$ and $\mathrm{A} 4$ ). After that, the association among FPST,

Table 1 - Description of the broiler houses used in the experiment

\begin{tabular}{|c|c|c|c|c|c|c|c|c|c|c|}
\hline House & $\begin{array}{l}\text { Height } \\
\text { (m) }\end{array}$ & $\begin{array}{l}\text { Lenght } \\
\text { (m) }\end{array}$ & $\begin{array}{l}\text { Width } \\
\text { (m) }\end{array}$ & Tile type & $\begin{array}{l}\text { Curtain } \\
\text { Type/color }\end{array}$ & Litter & $\begin{array}{l}\text { Flock density } \\
\quad\left(\text { bird } \mathrm{m}^{-2}\right)\end{array}$ & Genetic strain & $\begin{array}{c}\text { Ventilation } \\
\text { type }\end{array}$ & Total of birds \\
\hline A1 & 3 & 111 & 11 & Fiber-cement & Polypropylene/yellow & $\begin{array}{l}\text { Re-used/ } \\
\text { sawdust }\end{array}$ & 12 & $\begin{array}{l}\text { Ross }+ \\
\text { Cobb }\end{array}$ & $\begin{array}{l}\text { Positive } \\
\text { pressure }\end{array}$ & 15.000 \\
\hline $\mathrm{A} 2$ & 3 & 105 & 10 & Ceramic & Polypropylene/yellow & New/saw dust & 12 & Ross & $\begin{array}{l}\text { Positive } \\
\text { pressure }\end{array}$ & 15.000 \\
\hline A3 & 3 & 111 & 11 & Fiber-cement & Polypropylene/yellow & $\begin{array}{l}\text { New/rice } \\
\text { husks }\end{array}$ & 12 & Cobb & $\begin{array}{l}\text { Positive } \\
\text { pressure }\end{array}$ & 16.000 \\
\hline A4 & 3 & 150 & 15 & Fiber-cement & Polypropylene/blue & $\begin{array}{l}\text { Re-used } \\
\text { Rice husks }\end{array}$ & 13 & Ross & $\begin{array}{l}\text { Negative } \\
\text { pressure }\end{array}$ & 25.000 \\
\hline
\end{tabular}


FPD, and internal house environment parameters were submitted to the Principal Component Analysis (PCA). PCA was applied to the recorded data for each variable in each house (A1, A2, A3, A4) to correlate or to associate them by graphically observing the obtained vectors.

In all analyses, the significance level of $5 \%$ was adopted. Analyses were performed using Minitab software v.1.5 (Minitab, Inc., State College, PA, USA).

\section{RESULTS AND DISCUSSION}

Air temperature was the highest in $\mathrm{A} 2\left(29.16^{\circ} \mathrm{C}\right)$ and the lowest in $\mathrm{A} 3\left(26.6^{\circ} \mathrm{C}\right)$, as seen in Table 2. The recorded air relative humidity values were within the $50-70 \%$ range recommended by Medeiros (2001) and Tinôco (2001). The lowest air relative humidity was recorded in the positive-pressure ventilation house with new rice husks litter (A3). Medeiros et al. (2005) suggested optimal environmental temperature of 26 ${ }^{\circ} \mathrm{C}$, relative humidity of $55 \%$, and air velocity of $1.5 \mathrm{~m}$ $\mathrm{s}^{-1}$ for broilers between 22-42 $\mathrm{d}$ of age. Air temperature values were higher in $A 1, A 2$, and $A 4$ than in $A 3$. According to Silva et al. (2009) and Moura et al. (2010), when the thermal environment is beyond the threshold value of $22^{\circ} \mathrm{C}$ broiler performance is compromised.

Table 2 - Mean and standard deviation of the internal environmental parameters recorded in the studied houses.

\begin{tabular}{lcccccc}
\hline House & $\begin{array}{c}\mathrm{DBT} \\
\left({ }^{\circ} \mathrm{C}\right)\end{array}$ & SD & $\begin{array}{c}\mathrm{RH} \\
(\%)\end{array}$ & SD & $\begin{array}{c}\mathrm{AV} \\
\left(\mathrm{m} \mathrm{s}^{-1}\right)\end{array}$ & SD \\
\hline A1 & 29.02 & 1.35 & 70.20 & 10.34 & 0.86 & 0.43 \\
\hline A2 & 29.16 & 1.21 & 64.20 & 9.87 & 0.69 & 0.33 \\
\hline A3 & 26.60 & 1.53 & 58.01 & 7.22 & 0.41 & 0.60 \\
\hline A4 & 27.03 & 2.73 & 67.58 & 13.79 & 0.90 & 0.63 \\
\hline
\end{tabular}

$\mathrm{DBT}=$ air dry bulb temperature; $\mathrm{RH}=$ air relative humidity; $\mathrm{AV}=$ air velocity; $\mathrm{SD}=\mathrm{stan}$ dard deviation. $n=245$ (A1 and $A 2) ; n=425(A 3$ and $A 4)$.

The recorded variables were dry bulb temperature $\left(\mathrm{DBT},{ }^{\circ} \mathrm{C}\right)$, air relative humidity $(\mathrm{RH}$, $\%)$, and air velocity $\left(\mathrm{AV} \mathrm{m} \mathrm{s}^{-1}\right)$, litter surface temperature $\left(\mathrm{LST},{ }^{\circ} \mathrm{C}\right)$, litter humidity $(\mathrm{LH})$ and the degree of compaction ( $\left.\mathrm{LC}, \mathrm{kg} \mathrm{cm}^{-2}\right)$.

Mean litter surface temperature and litter humidity values found in $\mathrm{A} 3\left(25.83^{\circ} \mathrm{C}\right.$ and $\left.22.91 \%\right)$ were lower than those recorded in the other studied houses (Table 3). Pododermatitis incidence was higher in A3 than in the other broiler houses (Figure 1), which may be attributed to the new rice husks, which sharp edges may injury the birds' feet, resulting in subsequent footpad lesions. Rice husks are widely used as litter substrate in Brazil because they are cheap and widely available in all regions (Lopes et al., 2013). Broilers housed both in A2 and A4 presented similar pododermatitis results, while those in A1 showed a low incidence of the lesion.
Table 3 - Mean and standard deviation of litter temperature, humidity, and compaction in the evaluated houses.

\begin{tabular}{lcccccc}
\hline House & LST $\left({ }^{\circ} \mathrm{C}\right)$ & $\mathrm{SD}$ & $\mathrm{LH}(\%)$ & $\mathrm{SD}$ & $\mathrm{LC}\left(\mathrm{kg} \mathrm{m}^{-2}\right)$ & $\mathrm{SD}$ \\
\hline $\mathrm{A} 1$ & 29.53 & 1.37 & 21.66 & 3.22 & 21.30 & 4.75 \\
\hline A2 & 29.18 & 1.27 & 24.07 & 3.43 & 17.10 & 4.24 \\
\hline A3 & 25.83 & 1.34 & 22.91 & 7.66 & 12.08 & 7.27 \\
\hline A4 & 26.74 & 1.65 & 26.74 & 7.48 & 16.67 & 6.36 \\
\hline
\end{tabular}

( $L S T=$ litter surface temperature; $\mathrm{LH}=$ litter humidity; $\mathrm{LC}=$ litter compaction; $\mathrm{SD}=$ standard deviation. $n=245$ (A1 and $A 2$ ) and $n=425$ (A3 and $A 4)$.

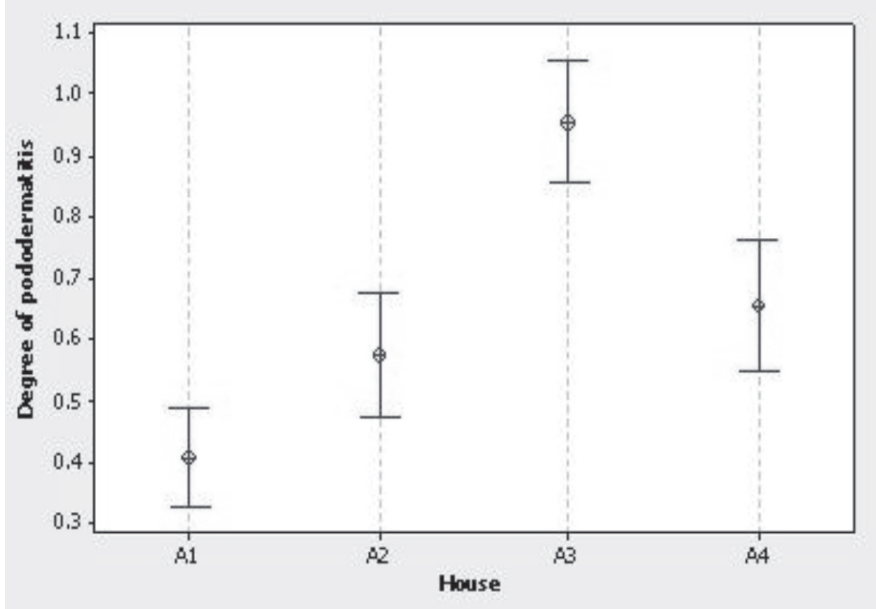

Figure 1 - The incidence of pododermatitis per studied house.

The main factor contributing for the development of pododermatitis is the litter quality. Substrates with sharp edges or chips may increase the prevalence and the severity of pododermatitis as a direct result of their abrasive action on the footpad. The function of the litter is to protect broilers' feet, minimizing the impact of the contact of the footpad with the floor (Bilgili et al., 2009). According to Refatti et al. (2009), woodshavings litter caused a higher incidence of footpad lesions than sawdust. Ekstrand et al. (1997) found that the footpad lesions may develop in less than one week of rearing. Mayne et al. (2005) found a high incidence of pododermatitis in 2 to 4 -d-old turkeys. The incidence of pododermatitis according to broiler age recorded in the present study is shown in Figure 2 .

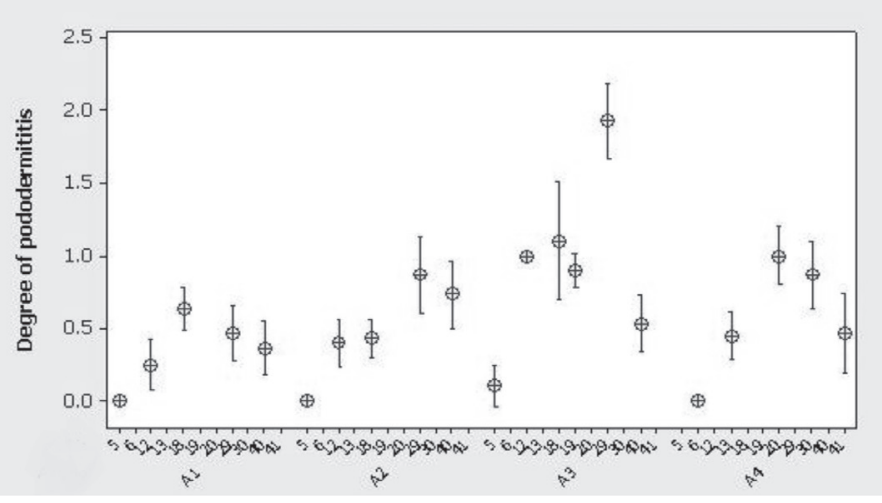

Figure 2 - Incidence of pododermatitis according to broiler age in each studied house. 
In all evaluated broiler houses, the incidence of footpad dermatitis (FPD) increased when birds were between 19 and 29 days old. This is the stage of adaptation to the grower feed, and according to Bilgili et al. (2010), diet composition, nutrient density and feeding programs affect broiler performance and health of broilers, directly or indirectly influencing the development of pododermatitis. Mendes et al. (2012) observed that FPD incidence in broilers increased as a function of age. Harn et al. (2014) evaluated broilers reared on dry or wet litter, and did not observe any performance, feed intake, behavior, or FPD incidence differences before 28 days of age. However, after this period, FPD incidence increased independently of litter moisture, resulting in poorer performance as a consequence of significant reductions in feed and water intake.

Different litter surface temperature were recorded among the evaluated broiler houses. The house with positive-pressure ventilation and new rice-husks litter (A3) presented $26.0{ }^{\circ} \mathrm{C}$ average litter surface temperature, while the house with positive-pressure ventilation and reused rice-husks litter showed $29.5^{\circ} \mathrm{C}$ average litter surface temperature (Figure 3).

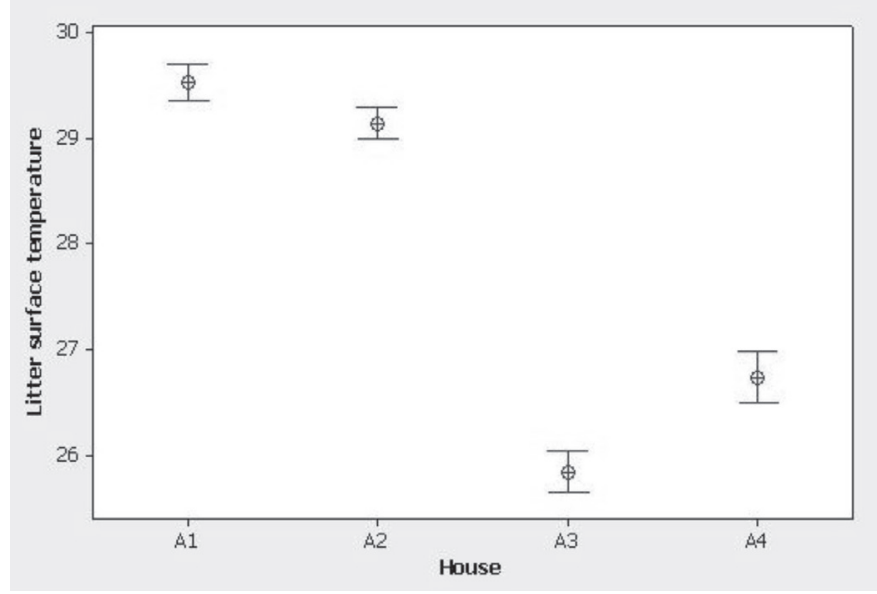

Figure 3 - Litter surface temperature distribution in the studied broiler houses.

There are several studies in current literature on broiler litter temperature. Miles et al. (2008) stated that litter temperature in houses with negative-pressure ventilation tend be similar to the environmental temperature. However, those authors recorded litter temperatures near $40{ }^{\circ} \mathrm{C}$ in the areas where birds were concentrated. Oliveira et al. (2000) observed that litter temperature in thermally-insulated houses was reduced $(p<0.01)$ in the morning. When comparing litter temperature at flock densities of 10, 16, and 22 birds $\mathrm{m}^{-2}$, the lowest litter temperature was recorded at the lowest flock density, probably due to less heat generation and lower excreta volume. Carvalho et al. (2011) analyzed litter temperature for 1-d-old chicks and verified that low litter temperature $\left(25.3-23.7^{\circ}\right.$ C) impaired chick growth. According to Dowsland (2008), litter temperature should remain within the range of $28-30{ }^{\circ} \mathrm{C}$ during the first days of rearing in order to remove excessive moisture, as moist litter may "cake", deteriorating litter quality.

The results obtained in PCA (Figure 4) indicate an association between footpad surface temperature (maximum and minimum) and house air temperature. Several studies show similar results (Yahav et al., 2005, Dahlke et al., 2005; Welker et al., 2008). Mello et al. (2011) found that heat stress during rearing may increase the incidence of footpad dermatitis, increasing carcass downgrade rates due to footpad lesions.

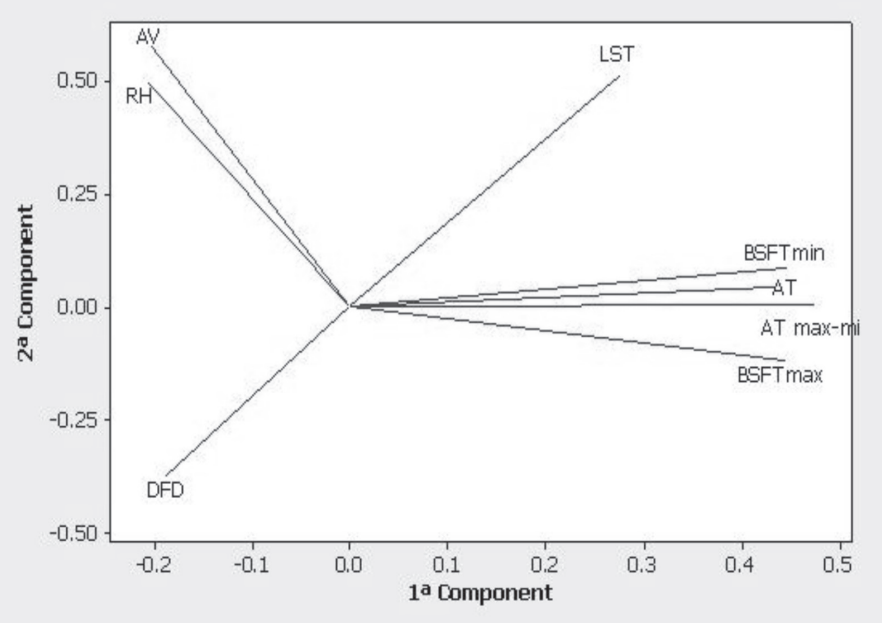

Figure 4 - Principal Components Analysis graph showing the association of environmental parameters, litter conditions, and pododermatitis.

The PCA showed an association between air velocity $(\mathrm{AV})$ and air relative humidity $(\mathrm{RH})$. High air moisture may result in wet litter and increase the incidence of pododermatitis. During the winter, when moist air is maintained in houses with low ventilation rates, the incidence of footpad dermatitis increased (Dawkins et al., 2004; Shepherd \& Fairchild, 2010).

Figure 4 shows that litter surface temperature (LST) was highly correlated with footpad dermatitis score. This result is in agreement with the findings of Birth (2011), who indicated a strong correlation between broiler surface temperature and litter surface temperature in houses with two ventilation systems (positive and negative).

Figure 5 shows an association of the score of pododermatitis with litter humidity, air temperature, litter temperature and with maximum and minimum footpad surface temperature in A1. Figure 6 shows the 
PCA analysis of A2, indicating an association between litter humidity and pododermatitis score.

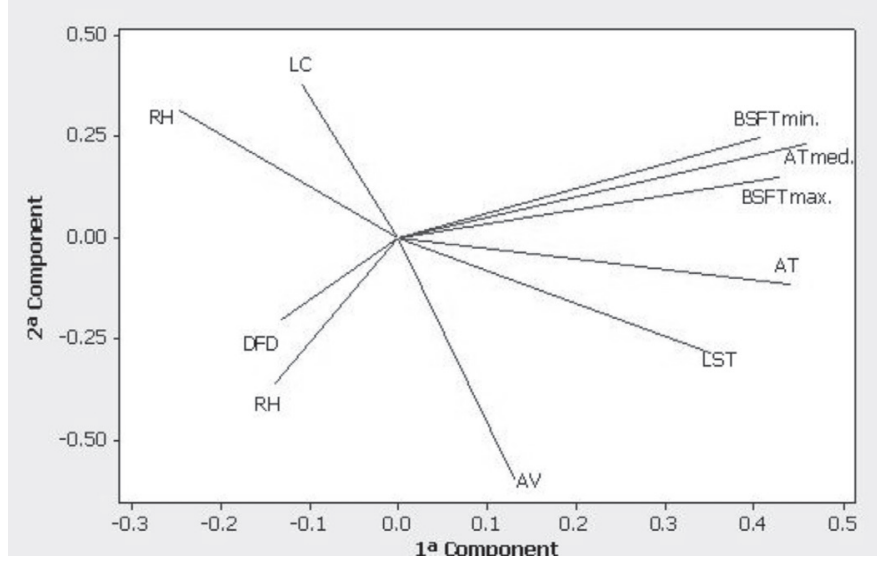

Figure $\mathbf{5}$ - Principal Components Analysis graph for house A1, showing the association of environmental parameters, litter conditions, and pododermatitis.

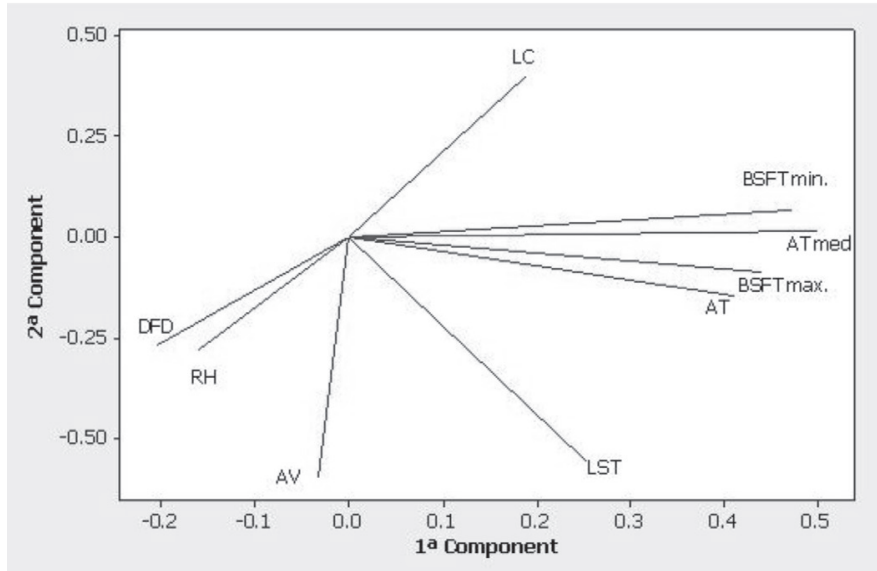

Figure 6 - Principal Components Analysis graph for house A2, showing the association of environmental parameters, litter conditions, and pododermatitis

According to Harn et al. (2014), high litter moisture promotes the development of footpad dermatitis in broilers. When excreta adhere to the broilers' feet, the contact with the corrosive litter is extended, increasing the severity of the lesions and of inflammation, resulting in necrosis (Tucker \& Walker, 1992). Dawkins et al. (2004) found that the presence of ammonia and moist litter deteriorate broiler health. The capacity of moisture absorption is one of the important features when choosing a litter substrate (Bilgili et al., 2009).

Litter compaction did not show any association with the incidence of pododermatitis. According to Ritz et al. (2014), compacted litter induces the volatilization of noxious gases and may increase the incidence of pododermatitis in broilers.

An association between minimum and maximum footpad surface temperature with the air temperature was found, but litter surface temperature was not associated with any other analyzed component in the present study. Nascimento (2011) found a similar relationship between house temperature and the surface temperature of the broilers legs.

Minimum and maximum footpad surface temperature was correlated with air temperature, as well as with air velocity and litter moisture (Figure 7). The graph results for A4 (Figure 8) show an association between minimum and maximum footpad surface temperature and air temperature and litter humidity.

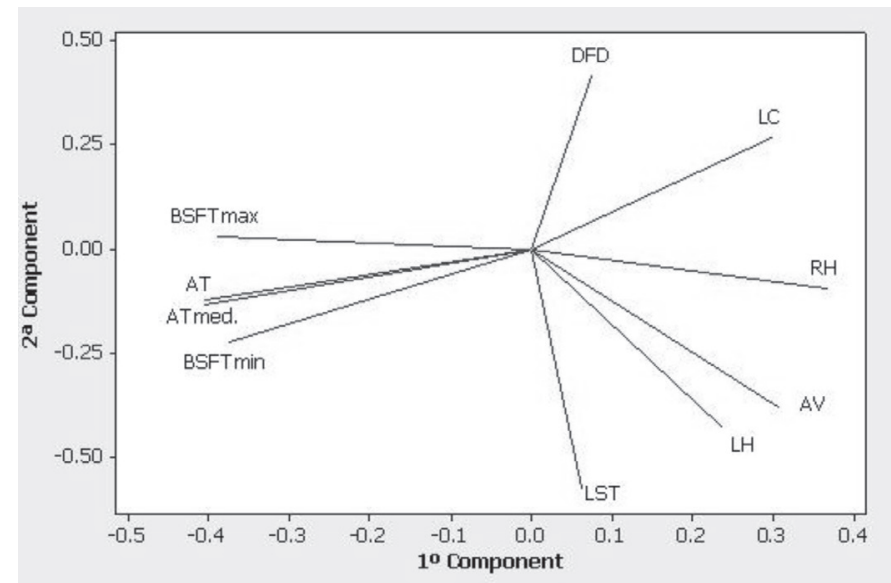

Figure 7 - Principal Components Analysis graph for house $A 3$, showing the association of environmental parameters, litter conditions, and pododermatitis.

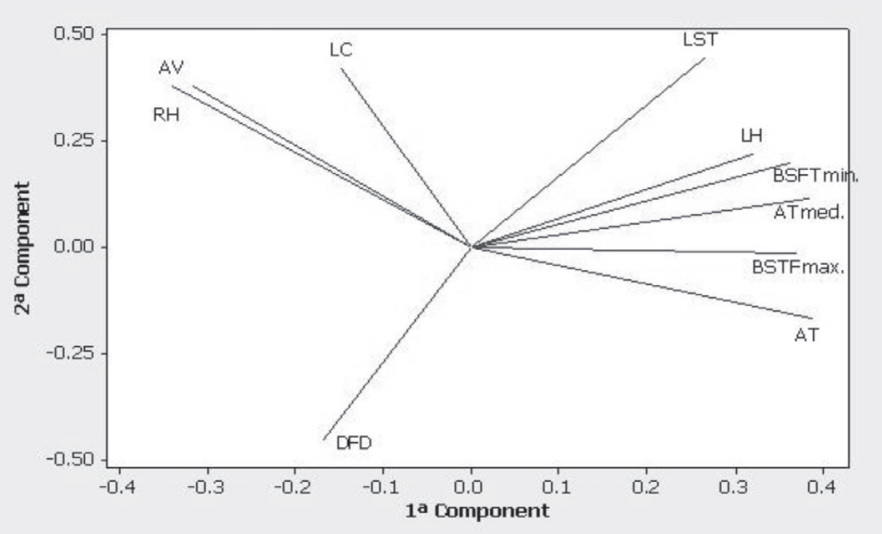

Figure 8 - Principal Components Analysis graph for house A4, showing the association of environmental parameters, litter conditions, and pododermatitis.

Several factors may influence litter humidity. High litter humidity causes "caking", increasing FPD incidence and severity, particularly in reused litter (Vieira et al., 2011). Broilers reared on dry litter present fewer feet lesions than those on humid litter (Traldi et al., 2007). The fast growth rate of some modern broiler strains has caused these birds to be more sensitive to heat stress (Skomorucha et al., 2010), as well as to be more susceptible to pododermatitis (Tucker and Walker 1992; Dawkins et al., 2004) than slow-growing broilers.

Air velocity was positively correlated with air humidity. Litter compaction was not correlated with 
either variables, and pododermatitis score was inversely proportional to litter surface temperature. Broiler leg abnormalities are often associated with their rearing environment, and such problems may be reduced by improving flock management practices (Dawkins et al., 2004; Cummings et al., 2005).

\section{CONCLUSION}

The Principal Components Analysis showed high incidence of pododermatitis in broilers housed in A3, probably due to the new rice husks used as litter substrate. The lowest pododermatitis incidence was recorded in house $A 1$, with reused sawdust litter. Although house A4 presented the most appropriate environmental conditions, the results were not conclusive relative to the incidence of pododermatitis under that rearing environment, in particular.

\section{ACKNOWLEDGEMENT}

The authors thank the Coordination of Higher Education (CAPES) for the scholarship and the Research Support Foundation of São Paulo (FAPESP), for the research grant.

\section{REFERENCES}

Bilgili SF, Hess JB, Blake JP, Macklin KS, Saenmahayak B, Sibley J. Influence of bedding material on footpad dermatitis in broiler chickens. Applied Poultry Research 2009;18:583-589.

Bilgili SF, Hess JB, Donald J, Fancher B. Practical considerations for reducing the risk of pododermatitis. Aviagen Brief 2010;1-8.

Brasil. Ministério da Agricultura e Reforma Agrária. Regras para análise da qualidade e produtividade. Brasília; 2010.

Cangar O, Aerts JM, Buyse J, Berckmans D. Quantification of the spatial distribution of surface temperatures of broilers. Poultry Science 2008;87:2493-2499

Carvalho TMR, Moura DJ, Souza ZM, Souza GS, Bueno LGF. Qualidade da cama e do ar em diferentes condições de alojamento de frangos de corte. Pesquisa Agropecuária Brasileira 2011;46(4):351-361.

Dahlke F, Gonzales E, Gadelha AC, Maiorka A, Borges SA, Rosa PS, et al. Empenamento, níveis hormonais de triodotironina e tiroxina e temperatura corporal de frangos de corte de diferentes genótipos criados em diferentes condições de temperatura. Ciência Rural 2005;35(3):664-670.

Dawkins MS, Donnelly CA, Jones TA. Chicken welfare is influenced more by housing conditions than by stocking density. Nature 2004;427:342344.

Denoix JM. Diagnostic techniques for identification and documentation of tendon and ligament injuries. Veterinary Clinics of North America: Equine Practice 1994;10(2):365-407

Dowsland I. Broiler foot health - controlling footpad dermatitis [Ross Tech Note]. Newbridge: Aviagen; 2008. p.1-5.
Ekstrand C, Algers B, Svedberg S. Rearing conditions and footpad dermatitis in Swedish broiler chickens. Preventive Veterinary Medicine 1997:31:167-174

Ekstrand C, Carpenter ET, Andersson I, Algers B. Prevalence and control of footpad dermatitis in broilers in Sweden. British Poultry Science 1998;39:318-324

Elson HA. Drinker design affects litter quality. Misset Poultry World $1989 ; 1: 8-9$.

Greene JA, Mccracken RM, Evans RT. A contact dermatitis of broilers clinical and pathological findings. Avian Pathology 1985;14:23-38.

Hoffmann G, Ammon C, Volkamer L, Sürie C, Radko D. Sensor-based monitoring of the prevalence and severity of footpad dermatitis in broiler chickens. British Poultry Science 2013;54(5):553-561.

Harn JV, Gunnink H, Jong IC. Wet litter not only induces footpad dermatitis but also reduces overall welfare, technical performance and carcass yields in broiler chickens. Journal Apply Poultry Research 2014;1:51-58.

Hashimoto S, Yamazaki K, Obi T, Takase K. Footpad dermatitis in broiler chickens in Japan. Journal Veterinary Medicine Science 2011;73(3):293297.

Haslam SM, Knowles TG, Brown SN, Wilkins LJ, Kestin SC, Warriss PD, Nico CJ.Factors affecting the prevalence of footpad dermatitis, hock burn and breast burn in broiler chicken.British Poultry Science 2007;48(3):264-275.

Lopes M, Roll VFB, Leite FL, Dai Pra MA, Xavier EG, Heres T, Valente BS. Quicklime treatment and stirring of different poultry litter substratesfor reducing pathogenic bacteria counts. Poultry Science 2013;92:638644.

Oliveira JE, Sakomura NK, Figueiredo AN, Júnior JL, Santos TMB. Efeito do isolamento térmico de telhado sobre o desempenho de frangos de corte alojados em diferentes densidades. Revista Brasileira Zootecnia 2000;29:1427-1434.

Martrenchar A, Boilletot E, Huonnic D, Pol F. Risk factors for footpad dermatitis in chicken and turkey broilers in France. Preventive Veterinary Medicine 2002;52:213-226.

Mayne RK. A review of the etiology and possible causative factors of footpad dermatitis in growing turkeys and broilers. World's Poultry Science Journal 2005:61:256-267.

Medeiros CM. Ajuste de modelos e determinação de índice térmico ambiental de produtividade para frangos de corte [tese]. Viçosa (MG): Universidade Federal de Viçosa; 2001

Medeiros CM, Baêta FC, Oliveira RFM, Tinôco IFF, Albino LFT, Cecon PR Efeitos da temperatura, umidade relativa e velocidade do ar em frangos de corte. Engenharia na Agricultura 2005;13(4):277-286.

Mello JLM, Borba H, Ganeco GA, Vieira LDC, Boiago MM, Souza PA Martins MRFB. Incidência de pododermatite de contato em frangos de corte submetidos a estresse térmico [cited 2014 Out 22]. Available from: pt.enformix.com.

Mendes AS, Paixão SJA, Marostega JB, Restelatto RC, Oliveira PAV, Possenti JCA. Mensuração de problemas locomotores e de lesões no coxim plantar em frangos de corte. Archivos Zootecnia 2012;61(234):217228.

Miles DM, Rowe DE, Owens PR. Winter broiler litter gases and nitrogen compounds: temporal and spatial trends. Atmospheric Environment 2008;42:3351-3363.

Moura DJ, Bueno LGF, Lima KAO, Carvalho TMR, Maia APAM. Strategies and facilities in order to improve animal welfare. Revista Brasileira de Zootecnia 2010;39:311-316. 
Mcilroy SG, Goodall EA, Mcmurray CH. A contact dermatitis of broilersepidemiological findings. Avian Pathology 1987; 16:93-105.

Nääs IA, Romanini CEB, Neves DP, Nascimento GR, Vercellino RA. Broilers surface temperature distribution of 42 day old chickens. Scientia Agricola 2010;67(5):497-502.

Nääs IA, Garcia RG, Caldara FR. Infrared thermal image for assessing animal health and welfare. Journal of Animal Behaviour and Biometeorology 2014;2(3):66-72

Nascimento GR. Termografia aplicada à avaliação do ambiente térmico de alojamento e do conforto térmico de frangos de corte [dissertação]. Campinas(SP): Universidade Estadual de Campinas; 2011.

Neili SD, Campbell JN, Grenne JA. Campylobacter species in broiler chickens. Avian Pathology 1984;13:777-785.

NCC - National Chicken Council. National chicken council animal welfare guidelines and audit checklist. Washington; 2010.

Payne CG. Factors influencing environmental temperature and humidity in intensive broiler houses during the post-brooding period. British Poultry Science 1967;8:101-118.

Refatti R, Restelatto R, Zielinski RP, Paixão SJ, Mendes AS. Tipos de cama e pesos iniciais ao alojamento sobre os parâmetros de umidade da cama e de incidências de lesões em frangos de corte. Anais do $3^{\circ}$ Seminário Sistemas de Produção Agropecuária; 2009; Dois Vizinhos, Paraná. Brasil.

Ritz CW, Fairchild BD, Lacy MP. Litter quality and boiler performance [bulletin 1267]. Athens: UGA Extension; 2014

Silva E, Júnior JY, Júnior RAB, Lopes MA, Damasceno FA, Silva GCAE. Desenvolvimento e validação de um modelo matemático para o cálculo da área superficial de frangos de corte. Engenharia Agrícola 2009;29(1):1-7.
Shepherd EM, Fairchild BD. Footpad dermatitis in poultry. Poultry Science 2010;89:2043-2051

Skomorucha I, Sosnówka-Czajka E, Muchacka R. Effect of therma conditions on welfare of broiler chickens of different origin. Annual Animal Science 2010;10(4):489-497.

Schmidt V, Luders H. Toe- footpad ulcers in fattening turkeys. Berliner und Munchener Tierarztliche Wochenschrift 1976;89:47-50.

Tinôco IFF. Avicultura industrial: novos conceitos de materiais, concepções e técnicas construtivas disponíveis para galpões avícolas brasileiros. Revista Brasileira Ciências Avícolas 2001;3:1-26.

Traldi AB, Oliveira MC, Duarte KF, Moraes VMB. Avaliação de probióticos na dieta de frangos de corte criados em cama nova ou reutilizada. Revista Brasileira de Zootecnia 2007;36:660-665.

Tucker SA, Walker WA. Hock burn in broilers. In: Garnsw- Orthy PC, Haresign W, Cole DJA, editors. Advances in animal nutrition. Oxford: Butterworth-Heinemann; 1992. p.33-50.

Vieira MFA. Caracterização e análise da qualidade sanitária de cama de frango de diferentes materiais reutilizados sequencialmente [dissertação]. Viçosa (MG): Universidade Federal de Viçosa; 2011.

Welker JS, Rosa AP, Moura DJ, Machado LP, Uttpatel R. Temperatura corporal de frangos de corte em diferentes sistemas de Climatização. Revista Brasileira de Zootecnia 2008;37(8):463-1467.

Weschenfelder AV, Saucier L, Maldague $X$. Use of infrared ocular thermography to assess physiological conditions of pigs prior to slaughter and predict pork quality variation. Meat Science 2013;95:616620

Yahav S, Shinder D, Tanny J, Cohen S.Sensible heat loss: the broiler's paradox. World's Poultry Science Journal 2005:61:419-434. 
